\title{
Transnationalism: current debates and new perspectives
}

\author{
Miriam Tedeschi (D) Ekaterina Vorobeva $\cdot$ Jussi S. Jauhiainen $(1)$
}

Published online: 9 August 2020

(C) The Author(s) 2020

\begin{abstract}
This article provides evidence-based results regarding current debates on transnationalism. It draws on the content analysis of the 50 most cited (according to the major academic databases and search engines in 2020) and the 50 most recent (published or forthcoming in 2019-2020) articles and/or books on transnationalism. The study analysed the main definitions of transnationalism, identified classification criteria for transnational experience, and reviewed the concept of transnationalism in the studied articles and books. In transnationalism, a broad range of economic, sociocultural, and political cross-border activities and practices, and their various combinations, modify people's sense of belonging to places; affect their citizenship and nationality; change their aspirations, imagination and decisions in everyday life; and influence their identity. In the studied academic literature, transnationalism was often associated with globalisation, migration, cosmopolitanism, multiculturalism, diaspora, post-migration studies, and internationalism. Transnationalism has an inner processual and in-becoming character, leading to difficulty in giving it a precise and clear
\end{abstract}

M. Tedeschi $(\bowtie) \cdot$ E. Vorobeva · J. S. Jauhiainen Department of Geography and Geology, University of Turku, Turku, Finland

e-mail: miriam.tedeschi@utu.fi

J. S. Jauhiainen

Institute of Ecology and the Earth Sciences, University of

Tartu, Tartu, Estonia theoretical definition. Many studies have shown the need for conceptual academic clarity regarding transnationalism, whether considering it from narrow or broad perspectives. Transnationalism is transformative, and powerful enough to trigger changes in contemporary societies. This article suggests a number of particularly intriguing research fields regarding transnationalism: telecommunications (ICT-Information and Communication Technology/the internet/social media), return migration (aspirations to return, and in relation to telecommunications), as well as the connection between bodies and the law (the incorporation of the body into transnational practices and in relation to the law).

Keywords Transnationalism - Content analysis . ICT $\cdot$ Return migration $\cdot$ Legal body

\section{Introduction}

Discussions centring on transnationalism are inherently multi- and trans-disciplinary (Vertovec 1999), spanning discourses on sociocultural activities (Kearney 1995), cross-border entrepreneurialism (Sommer 2020), everyday practices (Innes 2019), post-migration (Beauchemin and Safi 2020), political parties (Kernalegenn and Van Haute 2020; Pilati and Herman 2020), the right to vote, and dual identity and 
citizenship (Klingenberg et al. 2020) — to name only a few. Eminent scholars have explored the concept in depth and, over the years, have stressed different aspects of transnationalism (Portes et al. 1999; Schiller et al. 1992b; Vertovec 2009).

Connectedness across borders, the formality/informality of frequent cross-border activities and practices, and the high intensity and degree of cross-border exchanges are the main characteristics of a transnationalism 'from below', concerning individuals and civil society. Transnationalism has an inner processual and in-becoming character (whereas diaspora, for instance, mostly refers to specific groups and communities), leading to difficulty in giving it a precise and clear theoretical definition; therefore, instead of being based on a deductive approach, from theory to practice, the definition of transnationalism could more usefully be developed through a pragmatist inductive approach. Such an approach to transnationalism means defining it according to its actual use and empirical context, as recommended by Bauböck and Faist (2010) and suggested by Beauchemin and Safi (2020), defining the macro-, meso- and/or micro-level of the empirical context, and then deriving the theory. In this way the variables to study transnationalism and the methods to analyse it can be provided, but have limits that need to be examined in order to avoid incorrect or over-generalised conclusions.

In this article, we address the various definitions of transnationalism, highlighting their limits and opening up new lines of research. Our argument follows two research questions: how is transnationalism defined (or not defined) in the most cited and most recent scholarly works about the subject, and what are the most promising lines of research concerning transnationalism.

After this introduction, we (1) outline the Methodology used in this article; (2) analyse the existing theories about transnationalism, mainly derived from debates in the 1990s and early 2000s; (3) discuss the applicability of these theories to empirical research, while stressing the need to find criteria and variables that define transnationalism (and what it is not); and (4) highlight promising novel research directions for transnationalism studies, such as telecommunications (ICT/the internet/social media), return migration (aspirations to return and in relation to telecommunications), and the connection between bodies and the law (the incorporation of the body into transnational practices and in relation to the law). Furthermore, we pay attention to the topic of imagination as a guiding thread for possibly uniting these novel research topics.

\section{Methodology}

This research obtained evidence-based results regarding current debates on transnationalism, drawing on a database of the 50 most cited (Google Scholar, Scopus, and Web of Science) and the 50 most recent (published or forthcoming in 2019-2020) articles and/ or books about transnationalism. The 50 most cited articles indicated the widely recognised key scholarly theories of transnationalism, and the 50 most recent articles indicated the evolvement of the scholarly discussion regarding transnationalism. The main definitions and classifications for conceptually framing transnationalism have come from only a few scholars (as discussed in detail below) and are often repeated and reworked from the same original sources; therefore, the research paid particular attention to these main sources (as cited in the reference list), without explicitly citing all of them. Other sources repeating those definitions and classifications remain in the background (and may not be cited) to avoid duplication. Nevertheless, all the publications contributed to the empirical material for this research. The texts were analysed using empirically-driven content analysis to identify the main definitions of transnationalism, the main scholars, the related strands of thought, and the key and missing topics. In addition, other relevant scholars, who were not included in the list, are cited and used in the article. They provided important details that supported the definitions and classifications of transnationalism and helped to open up possible lines of future research (as discussed later in the article).

The content analysis of the publications about transnationalism on which the research was based was divided into three rounds. First, we identified the main scholars (such as Portes, Schiller, and Vertovec) based on their citation frequencies. Their thinking was scrutinised and the similarities and differences in their definitions of transnationalism were identified. From a methodological perspective, it was important to determine whether scholars of transnationalism used qualitative, quantitative, or mixed methods. In addition, we identified the broader geographical focus of 
the articles and the countries they discussed: Europe, Africa, North America, South America, Asia, and/or Oceania.

Second, using an abductive method (starting with our content analysis of the texts and then seeking most likely characterising keywords for transnationalism), we identified around 50 keywords relating to the topics discussed in, or absent from, the articles and books concerning transnationalism. Among the main keywords were assimilation, capitalism, citizenship, civil society, cosmopolitanism, diaspora, globalisation, identity, internationalisation, nationalism, neoliberalism, and migration.

Third, we recognised certain main terms relating to the adjective 'transnational' in the studied material. Common examples of such words were: community, organisations, activities/practices, social capital, relations, and citizenship, among others. Even though these classifications were present in the databases, they were not the key focus of this article, but constituted relevant background information and guided us toward the current and missing debates about transnationalism.

Following these three rounds of analysis of the articles and books about transnationalism, we identified promising novel lines of research, as will be discussed later in the article. These included telecommunications (ICT/the internet/social media), return migration (aspirations and in relation to telecommunications), as well as the connection between bodies and law (the incorporation of the body into transnational practices and in relation to the law).

\section{Main theories of transnationalism}

Transnationalism—definitions and theories

In the most relevant and recent literature regarding transnationalism, it was understood as being a component of globalisation, from which it cannot be separated; however, the two terms are not interchangeable. Klingenberg et al. (2020: 2) stated that globalisation refers to all activities spanning social, economic, and political fields that 'cause greater interaction and interconnectedness between countries and continents' (see also Levitt 2001). Indeed, 'in the early 21 st century, goods, information, services, financial capital and human beings are flowing across national borders at an ever-accelerating rate' ( $\mathrm{Li}$ and Teixeira 2007). On the other hand, transnationalism concerns individuals' and civil society's movements across borders (Kearney 1995; Peck 2020) and how increased global connectedness affects those movements. Following this line of thought, in this article we concentrate on transnationalism 'from below', mostly in relation to individuals and civil society (see Table 1) and using Hirst et al.'s definition of civil society, which does not include the state (or state-led organisations), but rather includes 'individuals, corporate bodies, associations, and large and complex organisations' (2001: 107). In general, 'civil society ... consists of groups, individuals and institutions which are independent of the state and of state boundaries, but which are, at the same time, preoccupied with public affairs' (Kaldor 1999: 210).

Schiller et al. (1992b) defined transnationalism as 'the processes by which immigrants build social fields that link together their country of origin and their country of settlement'. They continued: 'transmigrants develop and maintain multiple relationsfamilial, economic, social, organisational, religious, and political, that span borders. Transmigrants take actions, make decisions, and feel concerns, and develop identities within social networks that connect them to two or more societies simultaneously' (Schiller et al. 1992b: 1-2). These definitions highlighted the relevance of migrants' agency (Bauböck and Faist 2010) in a globalised world, covering many overlapping economic, social, and political fields and hinting that transnationalism 'ontologically' consists of relevant dynamic cross-border relationships and activities, regardless of the type (cultural, social, political, economic, etc.) of relationships involved. This process of meaningful relation-building is not static, but is continuously evolving and 'becoming', greatly contributing to the forging of people's dual or plural identities and sense of belonging.

Not all immigrants, however, become 'transnational', as Portes stressed (2001), so the phenomenon needs to be better defined and narrowed down (Bauböck and Faist, 2010) as 'a concept that seeks to cover an excessive range of empirical phenomena ends up applying to none in particular, thereby losing its heuristic value' (Portes 2001: 182). Nevertheless, since transnationalism remains a broad concept, it is challenging trying to tie together the disparate aspects of its activities and multidisciplinary dimensions, 
while at the same time establishing clear variables and limits. Moreover, cross-border activities have always existed in history (Foner 1997; Mintz 1998), so their role in the context of transnationalism today must also be highlighted. In this sense, 'much is distinctive about transnationalism today [in the 1990s], not only because earlier patterns have been intensified or become more common but because new processes and dynamics are involved' (Foner 1997: 356). This linking of transnationalism to the already-known phenomenon of cross-border activities was not a redundant operation, but allowed researchers to more explicitly point out and study 'transnational' practices and activities (Portes 2003). In order to narrow down the phenomenon of transnationalism, Portes (2001: 185) distinguished four categories of actions carried out across national borders: 'those conducted by national states; those conducted by formal institutions that are based in a single country; those conducted by formal institutions that exist and operate in multiple countries; those conducted by non-institutional actors from civil society'. He called the first two types international; the third type, multinational; and the fourth type, transnational [for an alternative classification of international and multinational see, for instance, Bauböck (2003)]. Transnational activities 'represent goal-oriented initiatives that require coordination across national borders by members of civil society' (Portes 2001: 186)— thus identifying transnationalism from below.

The majority of scholars have agreed that transnationalism is 'from below' (Smith and Guarnizo 1998) and concerns civil society, as well as individuals and their formal/informal activities: 'a "people-led" process that exploits the economic and political opportunities presented by globalisation and challenges the centralising tendencies of nationalism' (Al-Ali et al. 2001: 578-579). However, there is also transnationalism 'from above' (Østergaard-Nielsen 2003) in the corporate and inter-governmental sectors. Again according to Portes, transnationalism 'ontologically' consists of cross-border activities and goal-oriented relationships involving individuals, civil society, and non-institutional actors (thus restricting the field of research). Moreover, migrants need to regularly maintain these 'transnational' relationships and activities, otherwise they can no longer be considered transnational (Portes et al. 1999). In this sense, other scholars have suggested distinguishing between narrow and broad transnationalism (Itzigsohn et al. 1999), based on the degree/intensity and regularity of individuals' transnational activities, as already stressed by Portes et al. (1999). Itzigsohn et al. (1999) distinguished between 'the degree of institutionalisation of various practices, the degree of involvement of people in the transnational field, and the degree of movement of people within the transnational geographical space' (Itzigsohn et al. 1999: 317). From these studies, qualitative and quantitative variables to define transnationalism can be derived.

Vertovec (2003) supported the idea that grassroots resources and private citizens are regularly involved in transnational activities. These activities affect people's sense of belonging, loyalty, and sense of attachment. They become multi-local: found and retained in more than one locality (Klingenberg et al., 2020). Vertovec (2009) claimed that the meaning of transnationalism is grounded in six theoretical premises: social morphology (social networks spanning borders), type of consciousness (multiple identities and sense of belonging), mode of cultural reproduction (hybridisation of various cultural phenomena), avenue of capital (activities of transnational corporations), site of political engagement (cross-border public participation and political organisation through technologies), and (re)construction of 'place' or locality (creation of new social spaces across countries). Meaningful and constant crossborders relationships and activities connect all these aspects, which are inherently transformative, relevant, and widespread enough to bring about societal structural change. Indeed, they 'may contribute significantly to broadening, deepening or intensifying conjoined processes of transformation that are already ongoing' (Vertovec 2009). In this way, 'transnationalism has reconstructed localities, regrouping, as a result of the mobility of both people and ideas, the practices and meanings derived from multiple geographical and historical points of origin' (Rizvi 2019: 277). This has happened because of the greater 'extensiveness, intensity and velocity of networked flows of information and resources' (Vertovec 2004: 972); thus, being inherently in-becoming, transnationalism is transformative, powerful enough to trigger societal changes. Recent literature has already highlighted that distinctions such as integration versus transnationalism, or transnationals versus nontransnationals, should be revisited (Beauchemin and 
Safi 2020; Faist and Bilecen 2017). It is transnationalism itself, and its transformative nature, that challenges these dual categories and distinctions, pushing forward and challenging their limits and rooting them in the actual practices and activities of cross-border individuals.

In this sense, individuals' integration into host countries is not necessarily antithetical to transnationalism. Here, we are not referring to the normative and political dimension of integration, but rather to the migrant's 'adaptation processes' (Erdal and Oeppen 2013: 869) in the host country. These are not fixed processes, but are instead a relentless negotiation, Erdal and Oeppen (2013) continued, between individuals (or groups), whereby 'a membership' in a particular place is dynamically agreed, differences accepted or rejected, and hybrid identities continuously redefined. Indeed, in real life, an individual can hold multiple identities across borders (Lucas and Purkayastha 2007), but still be integrated into the host country, which is compatible with integration in the form of sociocultural transnationalism: 'transnational practices that recreate a sense of community based on cultural understandings of belonging and mutual obligations' (Itzigsohn and Saucedo 2002: 767). There is also a rejection-based transnationalism (Beauchemin and Safi 2020) that is conversely associated with segregation in the host country, often caused by racism. In this situation, transnational migrants increase their connections with, and activities in, the country of origin, since they feel that that is where they belong, rather than in the host country. This particular form of transnationalism takes at least two forms:

A symbolic one, with migrants retaining an identification with the home country as a reaction to the experience of discrimination and racism; and an economic one, with migrants investing at origin and so gaining satisfaction and prestige in their home society (in contrast to the frustrations encountered at destination) (Beauchemin and Safi 2020: 257).

Rejection-based transnationalism might lead to return migration (discussed later in the article). Regardless of the integration versus segregation distinction, and the numerous shades in-between them in terms of the identity and sense of place and belonging of the individuals, the question recently posed in the academic literature was whether everyone is becoming transnational (Beauchemin and Safi 2020). Studies have indicated how the dualism between the country of origin and the host country can be overcome. Transnationalism involves behaviours aimed at being and becoming cosmopolitan (with cosmopolitanism here referring to belonging to one large global community). Migrants in general (not only international migrants), and even non-migrant families that have close ties with transnationals, have meaningful connections that reach many countries besides the home country. At least two processes are at work here simultaneously: 'on the one hand the continuing importance of the nation and the emotional attachments invested in it, and on the other hand those processes, such as cross-border migration, which are transnational in form' (Westwood and Phizacklea 2000: 2). Both cross-border migration and emotional attachments can involve more than one country and lead to individuals' cosmopolitan ways of living. These are further reinforced by ICT, as discussed later in this article.

\section{Transnationalism-the empirical perspective}

Considering the empirical work on transnationalism, a key issue is how to measure it (Pötzschke 2012); how to find a threshold to distinguish transnational from non-transnational individuals; and whether this still makes sense in the information age, where everything is connected. The transnationalism literature has indicated the criteria to be refined in fieldwork that follows a pragmatist approach. As mentioned in the introduction, deductive theory-driven approaches play a limited role in this, given the inherently in-becoming, changing, and transformative nature of transnationalism. Vertovec suggested cross-fertilisation as a means to use and mix contributions and methods from various disciplines to analyse transnationalism. Inter-, multi-, and trans-disciplinary approaches are crucial. In this sense, for instance, 'though not without its problems and critics, social network analysis has operationalised many terms and concepts that researchers of transnational social formations would do well to bear in mind when collecting, analysing and describing data' (Vertovec 2003: 647). These include: the size of the network and its density, multiplexity (the overlapping of institutional spheres), clusters ('a specific area of a wider network with higher density than that of the network as a whole'), the strength (or 
weakness) of ties (Granovetter 1973), durability (how long relationships last over time, when they disappear, etc.), and frequency (the regularity of contact within the network). The use of social network analysis (mapping and measuring relationships and flows between people, groups, or organisations) as a way to measure transnationalism (in terms of transnational fields emerging as social structures) created 'a family of indices and strategies to capture and display variation in embeddedness and transnational span' (Molina et al. 2014: 234). Vertovec added:

Although all of the above terms and concepts define (and may be used to quantify) various aspects of social ties, it remains clear that such ties are not fixed. As well as being reproduced, networks are constantly being socially constructed and altered by their members (Vertovec 2003: 647).

Vertovec's insistence on the ontologically transient nature of transnationalism is reflected in the fragmentation of the discipline and in scholars' attempts to measure transnationalism with different variables and methods. The Horizon 2020 EUCROSS project, for example, defined indicators for measuring transnationalism (cross-border practices, divided into mundane practices and extraordinary practices) based on people's physical mobility, virtual mobility, and cosmopolitan consumption and competencies. They added variables relating to transnational background and private networks, such as being born abroad, having more than one citizenship, having parent(s) who were born abroad, having a partner who was born abroad, or having family members and/or friends from abroad. The specific measurement of 'extraordinary practices' challenges the concept of the 'regularity' of cross-border activities, demonstrating the fluidity and the changing nature of the phenomenon; thus, instead of measuring the regularity of such activities and practices, the focus should be on their intensity and personal relevance, and on the impact they have on identity and sense of belonging, especially in the contemporary information age.

Other attempts to define transnationalism through a measure of its elements and variables were made by
Ciobanu and Ludwig-Dehm (2020) and Wong (2007) — to cite only a couple. The latter's work relied on a survey which measured transnationalism as a dichotomous variable and as a scale (Wong 2007: 90). As dichotomous variable, those who were not transnational had only one (in that case Canadian) citizenship. For the scale, three variables were selected: 'citizenship status, family in country of birth, and travel back to country of origin' (Wong 2007: 91). Active citizenship was measured as a dichotomous variable and as two scales. Other variables were: civic participation, political participation, a sense of belonging, the importance of ethnic/cultural identity to the individual, and the individual's experience of ethnic/ racial discrimination. However, once again, such measurement cannot be universal because of differences between the countries that accept dual or multiple citizenship.

It is impossible to report all the multiple facets of transnationalism in one article, or to list the different types of variables that scholars have employed to measure (and limit) it; however, the main variables can be classified as the type of actors involved (organisations or private citizens); the type of activities (sociocultural, economic, political); the degree of integration/segregation; the degree of cosmopolitanism (whether the actors involved have built meaningful connections with more than two countries, rather than only with the country of origin and the current host country); the degree of emotional belonging (to what extent the individuals feel that they belong to one rather than another country); and the degree/intensity of connections with the home (or other) country. Here, an additional challenge is posed by the notion of a 'country', because the migrants are connected only to some people, organisations, and institutions in the country of origin or the destination country. Ultimately, countries are socially constructed, imagined communities of which people perceive themselves to be part (Anderson 1983). Overall, despite such criteria, researchers may still define transnationalism differently, according to their specific empirical context and the fieldwork (Table 1). 
Table 1 Summary of the main definitions of transnationalism (which may overlap)

\begin{tabular}{|c|c|}
\hline Type of transnationalism & Definitions \\
\hline $\begin{array}{l}\text { Transnationalism 'from } \\
\text { above' }\end{array}$ & $\begin{array}{l}\text { 'Home country policies that channel the transnational } \\
\text { activities of migrants' (Hourani 2012) }\end{array}$ \\
\hline $\begin{array}{l}\text { Transnationalism 'from } \\
\text { below' }\end{array}$ & $\begin{array}{l}\text { 'Migrant practices relating to their country of origin in } \\
\text { economic, cultural and political terms' (Hourani 2012) }\end{array}$ \\
\hline Broad transnationalism & $\begin{array}{l}\text { 'Refers to a series of material and symbolic practices in } \\
\text { which people engage that involve only sporadic } \\
\text { physical movement between the two countries, a low } \\
\text { level of institutionalization, or just occasional personal } \\
\text { involvement, but nevertheless include both countries as } \\
\text { reference points' (Itzigsohn et al. 1999: } 323 \text { ) }\end{array}$ \\
\hline
\end{tabular}

Narrow transnationalism

Rejection-based (reactive) transnationalism

Transnationalism: crossborder activities and social processes

Transnationalism: economic, sociocultural, and political

Minor transnationalism

Reverse transnationalism
'Refers to those people involved in economic, political, social, or cultural practices that involve a regular movement within the geographic transnational field, a high level of institutionalization, or constant personal involvement' (Itzigsohn et al. 1999: 323)

Symbolic: 'Identification with the home country as a reaction to the experience of discrimination and racism';

Economic: Investment 'at origin and so gaining satisfaction and prestige in their home society' (Beauchemin and Safi 2020: 257)

'Multiple ties or interactions linking people or institutions across the borders of nation-states' (Vertovec 1999: 447);

'Emergence of a social process in which migrants establish social fields that cross

geographic, cultural, and political borders' (Schiller et al. 1992a)

'Economic initiatives of transnational entrepreneurs who mobilize their contacts across borders in search of suppliers, capital and markets';

'Political activities of party officials, government functionaries, or community leaders whose main goals are the achievement of political power and influence in the sending or receiving countries';

'Socio-cultural enterprises oriented towards the reinforcement of a national identity abroad or the collective enjoyment of cultural events and goods' (Portes et al. 1999: 221)

'Cultural transversalism [that] includes minor cultural articulations in productive relationship with the major (in all its possible shapes, forms, and kinds), as well as minor-to-minor networks that circumvent the major altogether' (Lionnet and Shi 2005: 8)

Second generation return to homeland and their links to the country of birth (King and Christou 2010; Reynolds 2011)
Main authors

Michael Peter Smith, Luis Eduardo Guarnizo, Jose Itzigsohn, Sarah Mahler, Eva Østergaard-Nielsen

Michael Peter Smith, Luis Eduardo

Guarnizo, Alejandro Portes

Jose Itzigsohn, Carlos Dore Cabral, Esther Hernandez Medina, Obed Vazquez

Jose Itzigsohn, Carlos Dore Cabral, Esther Hernandez Medina, Obed Vazquez

Jose Itzigsohn, Silvia Giorguli Saucedo, Cris Beauchemin, Mirna Safi

Steven Vertovec, Nina Glick Schiller, Linda Basch, Cristina Blanc-Szanton

Aleiandro Portes, Luis Eduardo Guarnizo, Patricia Landolt

Francoise Lionnet, Shu-mei Shih, Alvin Wong

Russell King, Anastasia Christou, Tracey Reynolds 


\section{Promising fields in the study of transnationalism}

From the analysis of the literature, specific relevant lines of research emerged that could be explored in the future. In the following, we suggest telecommunications (ICT/the internet/social media), return migration (aspirations to return, mainly in relation to telecommunications), and the legal aspects of the body in transnational experiences. These topics-or some aspects of them-are under-researched, as evidenced by our content analysis; thus, while ICT is widely discussed in the literature, aspects such as the consequences of ICT on migrants' mobilities/immobilities and its enabling of their simultaneous memberships in multiple social, cultural, and political communities, as well as the creation of multiple identities across borders, are worthy of further investigation. Also generally under-researched is how the migrants' bodies and movements adapt, in their everyday micro-practices, to the overlapping of various (and often contradictory) international and national laws and regulations and how this is connected to transnational experiences. Finally, in return migration, which is generally widely discussed in the academic literature, a promising under-researched topic is how return aspirations are connected and modified by telecommunications, especially by the internet and social media usage.

As is clear from the above, all these topics partly overlap and connect with the individual's imagination - with his/her being part of imagined home and host communities influenced by the media, social media, and various online social networks (Kavoura and Borges 2016) —as a transversal driver that is highly conducive to transnational behaviours, activities, and practices. In this sense, imagination 'connotes various ways of being transnational that as yet have no viable political, economic, and social framework to sustain adequately the possibilities they might embrace' (Hitchcock 2003: 2-3).

\section{Telecommunications: ICT/the internet/social} media

In the literature on transnationalism, the notions of telecommunications and transnationalism have often been, and still are, tightly connected. Indeed, the goal of telecommunications-to connect individuals over distances, regardless of their place or country-is inherently transnational (Waldinger 2013). Transnationalism and the consumption of telecommunication products seem to correlate with a certain set of background variables. Virtual and physical mobilities are dependent on the socioeconomic status of people. Digital divides (individuals' internet access and resources, social media, and their impact on these individuals) still exist according to social status, gender, and urbanity (Chen 2013), but they are shrinking as mobile phones and internet access are becoming ubiquitous. Wealthy people, those with higher education, the younger generation, employed men, and people living in urban areas generally have better access to, and skills for using, the internet and social media and have greater financial resources to facilitate a transnational lifestyle (Recchi and Favell 2019). According to Recchi and Favell (2019), higher education levels and foreign language skills are more relevant factors than economic status. Furthermore, the younger generation is more familiar with information technology than older people. Regarding physical mobility and gender differences, women more often travel virtually than physically; also having one non-national parent in a family encourages virtual, but not physical, mobility.

Even though telecommunications and transnationalism mutually reinforce each other in various ways, and in relation to a wide range of variables, the causeand-effect relationship between the two phenomena is hard to identify. One possibility is to use the concept of imagination in relation to places and communities to reinforce their connections. The notion of 'transnationalism online' or 'digital transnationalism' [coined by Starikov et al. (Starikov et al. 2018)] indicates how intersections between the media and transnationalism can result in a qualitatively new phenomenon (Sun and Sinclair 2016), which has yet to be studied in depth (Lubbers 2018). They believed that the development of online communication channels enables instant, voluntary, often anonymous, and simultaneous memberships in multiple social, cultural, and political communities (Foner 1997); however, unlike traditional participation in social group activities, such involvement is characterised by instability, flexibility, constant change, and loose ties. This approach suggests new research questions relating to changes in belonging to 'imagined communities' (Anderson 1983) with the advent of the internet, and, in particular, in the notions of national and local, how 
they are affected by the mass-mediated imaginary (Pelliccia 2019), and whether and how the role of geographical proximity has changed as the crucial factor in tying communities together. Indeed, the hybrid augmented reality between physical and digital spaces is creating cognitive, imagined (but no less real) travels (Hillmann et al. 2018; Koikkalainen and Kyle 2016), which bring another novel aspect to the study of digitally-impaired transnationalism.

Overall, telecommunications allow citizens to 'inhabit trans-spatial and transtemporal imaginaries that dissolve the fixity and boundedness of historical nationhood and state territorial imperatives' (Ong and Nonini 2003: 288). The transnational character of media products presents both new challenges and opportunities (Smith 2003) to nation states. Mediated transnational lifestyles may lead to 'eroding not only the nation state' but also national identities (Aksoy and Robins 2003); therefore, located in the context of other states, not only one's own national identity, but also other's national identities, are questioned, redefined, and modified (Iwabuchi 2019) — and potentially challenged and imagined differently.

The consumption of certain media products, prior to factual migration (including return migration), might lead to aspirations to virtual or even physical mobility. Indeed, Portes (2003) claimed that virtual travel and physical mobility are positively correlated. Media can help normally immobile individuals to cross national boundaries and, thus, visit a " "third space" of transnational encounters' (Ong and Nonini 2003: 309). In summary, media have the potential to sustain various kinds of imagination and, therefore, transnational behaviours, at both the national and global scales. Additionally, in the current era, in which social media is increasingly present in people's everyday lives, both information and misinformation (including news and fake news) are distributed rapidly across populations, heavily shaping their imaginations, their actions, and their decisions.

Nevertheless, being just a call or a 'chat' away does not always mean being fully informed about, or engaged in, transnational activities. Carling (2008) raised the question of both the connecting and disconnecting effects of telephoning. He noticed that 'even migrants who maintain close contact with their non-migrant relatives and return to their country of origin on a regular basis have limited information about the daily lives of non-migrants' (2008: 1463); however, by the 2020s, it has become increasingly common to share all kinds of mundane details about one's everyday life on social media. Sometimes it is irrelevant whether particular social media group members live in the same city or in different countries; nevertheless, the information gaps provide space for imagination and preconceptions about life on the other sides of borders. Recchi and Favell (2019) argued that the limitations of virtual relationships may encourage people to aspire to physical mobility. Likewise, intense virtual connections may make migration easier, since an individual may move into a locality and circumstances with some pre-existing knowledge and, similarly, occasional visits to a former country of origin sustain further virtual communication. Overall, the research on the complex relationships between virtual and physical mobilities has provided some understanding of the consequences of physical absence and occasional visits for transnationals and their families, and about the role of imagination in these mobilities/immobilities.

Nevertheless, the maintenance of transnational connections may prevent the establishing of beneficial networks in a new country of residence. Verdery et al. (2018) suggested that sustaining friendships in the country of origin can mean withdrawing from friendship networks in the country of residence, potentially leading to an increasing separation of transnationals and their segmented integration into marginalised groups (even though this dualism of integration versus transnationalism has been questioned, as we showed in the previous section). The longer transnationals live in a new destination, the wider local networks they enjoy (Comola and Mendola 2015), regardless of their transnational ties, although transnationalism is an inbecoming phenomenon, so it is not possible to draw any generalised conclusions. In this sense, similarly to globalisation, its non-linear movement has been demonstrated, with transnational ties intensifying in one period of time and decreasing in another (Jones 2019): for certain individuals, transnationalism is a temporary, rather than a constant, way of living, where physical and virtual, mobilities and immobilities, are lived as flexible, loose, and non-linear spaces inbetween, and where imagination forms a bridge across these 'in-between categories'.

In summary, telecommunications and transnationalism mutually reinforce each other through various products, practices, and imaginations. Virtual mobility 
and physical mobility are characterised by strong interdependence and tend to sustain each other. Future research could therefore focus on how mobility and immobility are connected (Ehrkamp 2019) via individuals' simultaneous virtual memberships in multiple social, cultural, and political communities, and how an individual's visits to a country of origin may lose their significance as a necessary prerequisite for knowing what is going on in that country. The majority of empirical studies about transnationalism have focused on Europe, North America, and specific places in Asia. More analyses are needed relating to other contexts that have recently experienced a wider distribution of mobile phones and internet access, such as Africa. Another important topic to address is the use of the internet and social media among forcedly displaced people who are obliged to cross national borders and to live a contingent transnationalism (Merisalo and Jauhiainen 2019, 2020). Given the importance of online social networks, there is a need to study how relevant to the study of transnationalism is a clear distinction between mobility and immobility, or even between the physical and virtual, as has been discussed in post-migration studies (Moret 2016; Yoon 2016).

\section{Return migration}

The connection between transnationalism and return migration (aspiration) is an increasingly relevant topic (Carling and Erdal 2014; Carling and Pettersen 2014; De Haas and Fokkema 2011; Guarnizo 1997; Horst 2007), specifically in relation to imagination and telecommunications. As previously mentioned, in transnationalism, connections with the country of origin are not constantly maintained (transnationalism per se is not linear, but rather a fluctuating, inbecoming process), but often change over time; hence, a migrant may not remain transnational forever. Nevertheless, transnational connections with the country of origin might be strong enough to shape the aspirations, motivations, imaginations, and actions of transnationals. In this sense, the connections may even induce a return to the country of origin (Carling and Erdal 2014) or, at least, be relevant enough for a migrant to become aware of what kind of context he/ she might be returning to in the country of origin, or to decide not to return there.

In the literature about transnationalism, return has been conceptualised, not necessarily as a permanent move, but rather as a crucial part of the fragmented journeys of transnationals (Carling and Erdal 2014; Iaria 2014). Transnationalism and return migration are embedded in personal ties that introduce emotions, beliefs, and imagination into the debates. Return visits also proved to be connected with citizenship, belonging, and transnational identity negotiation for migrants (Carling and Erdal 2014; De Bree et al. 2010; Duval 2004). Scholars identified the importance of temporal and spatial dimensions in these practices (Carling and Erdal 2014): indeed, transnational practices, and return aspirations, can significantly change over time. Moreover, the geographical proximity between the country of origin and that of current residence influences the frequency of visits and even communication, thus having an impact on the transnational lives of migrants (Iaria 2014). The frequency of visits and communication also, obviously, has an impact on both the former home community and the current host community (which has become, or might become, one's home community).

Nevertheless, the cause-and-effect relationship between transnationalism and return migration remains hard to detect. Some quantitative studies have shown that transnational practices form a necessary basis for return migration; for instance, Carling and Pettersen (2014) demonstrated that developed transnational practices resulted in the higher return aspirations of immigrants. However, visits to a former home country may help to prevent the romanticising of one's homeland; for example, Chang et al. (2017) claimed that trips to a country of origin reconfirmed the rightfulness of the decisions some Koreans made to immigrate to New Zealand and reinforced their attachment to the host country.

Reasons for returning might stem from the prereturn transnational practices of migrants. Supporting social and personal connections, making investments in the infrastructure of the former home location, or sending remittances home gives returnees visibility back in the former home country and among related communities, creates high social status, and assists in future reintegration. Lietaert et al. (2017) specified that remittances may act as a strategic investment, aimed at improving living conditions in a place where a migrant plans to settle in the future. It is common for migrants who aspire to return to use remittances to build a house or purchase another property in their former country of origin; for instance, in Dakar, 
Senegal, 'the majority of building projects are initiated and sustained by transnational migrants who send money to families, business partners, and contractors in the city' (Melly 2010: 39). Based on the case of Italians in Switzerland, Wessendorf (2007: 1090) claimed that 'owning property in Italy not only legitimised the return as a strategically possible, final conclusion of the migration plan, but it also provided a symbolic site for the (re)united family and an investment that linked the future generations to the country of origin'. Moreover, involvement in the activities of transnational companies facilitates the easy mobility of individuals between their former homes and current host states (King and Christou 2014; Kunuroglu et al. 2018). The transnationality of households with, as a rule, one family member abroad proved to be a temporary strategy and resulted in the ultimate return of the breadwinner (Kunuroglu et al. 2018); furthermore, the transnational family might use the return as a punishment, education, or rehabilitation of their children (Bolognani 2007). Regarding emotional connections, often biased information about life in the country of origin, received via different communication channels such as TV and social media, may trigger an idealisation of the homeland. This imaginary homeland often results in nostalgia, homesickness, a 'myth of return' or 'dream of return', with moving back perceived as highly desirable, but rarely implemented (King and Christou 2014; Kunuroglu et al. 2018; Wessendorf 2007). As Bolognani (2007: 65) stated: '[the] imaginary homeland is the antidote to frustration: if things are not good here for younger transnationals, they need to believe that elsewhere there is a place where working towards personal wellbeing is possible'.

In addition to the pre-return migration phase, transnationalism has also been discussed in relation to a post-return phase. The so-called 'reverse transnationalism' of returnees, sustaining connections with a host state after returning to a country of origin, proved to be crucial for migrants' well-being and financial status (Carling and Erdal 2014; De Bree et al. 2010); thus, returning does not put an end to transnational practices and mobility and migrants may still follow their pre-return trajectories, utilising their social and professional networks (Iaria 2014). Furthermore, reverse transnational practices are especially common among second-generation migrants, who 'return' to their ancestral homelands, but who were not born or never resided there (King and Christou 2010).

Living across borders and having hybrid identities, transnationals often feel that they do not fully belong anywhere. Tsuda (2013: 184) assumed that 'it is also possible that ethnic return migrants who suffer considerable exclusion and discrimination in both their countries of birth and their ethnic homelands may adopt non-nationalist, diasporic ethnic identities that are not based on loyalty to either nation-state'. As a result of unsuccessful returns, as well as weak integration into a host state, transnational consciousness might be developed (Vertovec 1999: 450), and this consciousness might be grounded, not only in the complex emotional and imaginary lives of transnationals, but also in physical ones; for instance, constantly moving across borders, migrants 'access the best of both worlds' - the best products, the most convenient services, or the cheapest human labour (Horst 2007). Transnational mobility can thus be conceived as a strategy of individuals to enhance benefits and increase resilience, although continuous commuting can be a time-consuming and tiring experience.

A future promising line of research is to what extent the aspiration to return is conditioned by telecommunications, in terms of the internet and social media usage. Telecommunications facilitate transnational individuals' everyday contact with the country of origin, so it is important to study what kind of content (formal institutional, informal friendship-based, or various truthful and fake news groups) influences the return migration aspirations and the actual return migration of transnationals. It should also be taken into account that not all people can return, even if they would like to; for example, many forcedly displaced people, or those whose country of origin is suffering economic hardship. In these cases, 'protracted' transnationalism as a continuous imaginary return can be an important element shaping an individual's identity; however, while such an identity prevents an individual's (forced or voluntary) assimilation into the host country, it also creates challenges for his/her potential reintegration into the home country. The successful and failed reintegrations of returned transnationals, and their overall impact on the society of the former country of origin, remain important topics to be investigated. 
The body and the law

Gender-related and feminist literature on transnationalism is extensive (to cite but a few: Gamburd 2000; Kea 2020; Lionnet and Shi 2005; Sahoo and Purkayastha 2020; Salih 2003; Wong 2020). A promising line of research based on this literature is to further explore the relationship between transnationalism, the body, and the law. The strand of thought relating to body politics (and even biopolitics) has already shown how society greatly influences the body and its movements. Moreover, bringing attention back to the body in the field of transnationalism studies would foster understanding of 'three crucial aspects of the incorporation process: identity formation, economic mobility, and transnational practices' (Brown 2016: 14).

In particular, more attention should be paid to the effect of the law and legal practices on the everyday lives (including the bodies' movements and choices) of transnational migrants. The focus should be on the connections between the everyday micro-practices of adaptation and the (often contrasting) legal requirements of the countries with which the transnational migrants are connected. In migration studies, the new materialism focuses, among other topics, on the definition of the identity of migrants as never fully completed bodies: beings always in-becoming, whose 'borders' are always challenged in, through, and by interactions with other bodies-in-space (Papadopoulos and Tsianos 2008) and with the law. Transnationalism studies could be conducted to discover how transnationals imagine their bodies across borders, the belongingness of such imagined bodies to specific countries, and the (potential) differences between the imagined transnational bodies and the bodies incorporated into everyday micro-activities and legal frameworks in host countries (Choo 2006). Brown (2016) highlighted how even withdrawing money from an ATM in a new host country requires that the person re-educate his/her body to micro-movements to which he/she is unaccustomed. The re-education of the body is an everyday micro-activity ultimately aimed towards integration, so as not to be pointed at as 'the different' or the 'foreigner'. In general, this involves the need to negotiate the everyday in the new spatiolegal environment of the new country, albeit with an underpinning spatio-legal layer inherited from the home country, of which the body of a transnational is materially made. Some bodies succeed in the negotiation and manage to move-in-space in the way that the written and non-written rules of the new country indicate; some do not, with material consequences for how they come to terms with themselves and their transnational conditions, build their own social networks, integrate successfully (or not), and deal with the bureaucratic procedures required by states. Of particular interest as a sub-topic here are the bodies of migrant mothers, who leave their own families to look after the children of full-time working women in industrialised Western countries, as well as in the middle and upper class households of Asia ..., the Middle East ..., and Central and Latin America' (Lutz and Palenga-Möllenbeck 2015: 140). This is an example of the so-called circulation of care, which accounts for the increased demand for caregivers and, consequently, the 'increasing feminisation of migration worldwide' (Lutz 2018: 578). When women leave their own children (who are looked after by other members of the family) to find jobs as carers for other children elsewhere, the reunification of transnational families may happen, but is likely to be hard to achieve: indeed, 'live-in caregivers in particular are obliged to cohabitate with their employer, and cannot run a separate household with their families' (Lutz 2018: 580). How do the bodies of these mothers change when adapting to (and adopting) the laws and regulations of different countries-and what are the consequences for the children who are left behind? Specifically in connection with ICT, how does the physical absence of mothers from the family of origin affect their relationships with their children-and to what extent it is possible to compensate for the 'absent body' by using computer-mediated communication? Baldassar and Merla recognised that this subject deserves further investigation:

The fact that migrants can, to various degrees, maintain a (sometimes daily) virtual presence in the life of their families via the use of communication technologies ... is both underexplored and undervalued, as are the visits home to attend family events such as weddings ... or for caring purposes (2014: 28).

In general, 'critical feminist care research today is concerned with the empirical investigation of how care work is shaped by moral norms and power structures' (Lutz and Palenga-Möllenbeck 2015: 144), 
at the same time highlighting the emotional suffering caused by the exercise of motherhood at a distance. Even though less emphasised by the literature so far, these elements may bring attention back to the relationship between the feminine body and laws and regulations.

This topic of the body and the law also needs to be combined with the overarching theme of imagination, which transversally crosses the majority of literature on transnationalism. The imagined body and the actual body shaped by national and international laws, as well as transnational regulations and local (even nonwritten) rules, generate imaginaries crossing countries, mostly via social networks; for instance, some transnationals used 'their bodies to perform upward mobility to those back home and saw transforming their bodies as a key to actual incorporation' (Brown 2016: 24). These performances, with shared pictures showing off individual wealth that, in fact, does not exist in the new country of residence, cross social networks and shape the imaginations of families and friends who remain in the home countries: 'immigrants alter their dress and grooming practices to symbolise belonging ... and transnational ties' (Brown 2016: 15). Such selective or purposefully faked depictions of a country have also been used by asylum-related migrants, who often wear 'masks' and construct fake identities (Papadopoulos and Tsianos 2008). Many purposefully create an image of success that is visually effective for transmission online by selecting specific clothing (albeit borrowed) and easily-recognisable 'iconic' locations (even those that are usually never visited) for these visual body-related electronic transmissions. A specific focus on the body in transnationalism studies could also open up new empirical investigations of the transnational use of health services-still under-researched in the transnationalism field. In addition, especially concerning healthcare services, where the body and feelings such as trust play a major role, it is necessary to explore how transmigrants choose whether and where to be cured, and why, and the role of language and feelings of belonging on the one hand, and of the law on the other hand, in these choices: 'transnational ties shape healthrelated behaviours of migrants from the use of healthcare services to health preferences' (Kelleher et al. 2020: 1).

\section{Conclusions}

This article has analysed the most recent and relevant research concerning transnationalism and how it contributes to framing transnational behaviour, activities, or practices. So far there is no universal definition of transnationalism: what is included in it and excluded from it. Furthermore, the ontological character of transnationalism is processual and 'in-becoming'; therefore, what activities, practices, and behaviours are transnational-and what are notlargely depends on the methods and materials used and on the variables proposed by the researchers. In the information age, it is already debatable whether one can be fully 'not transnational'.

However, as common points, transnationalism 'from below' (from the viewpoint of individuals and civil society) concerns cross-border (sociocultural, political, and/or economic) activities, practices, and behaviours that are meaningful, affect the identity and sense of belonging of people, and are carried out on a regular (not exceptional) basis in the everyday lives of individuals-even though this latter criterion can be questioned, as discussed earlier. From these common (although fluid and ever-changing) points, variables can be derived that describe the level to which activities, practices, and behaviours are transnational. The international literature is full of examples of these variables, which vary greatly, depending on whether the used methods are quantitative, qualitative, mixed, or comparative. The majority of the studies on transnationalism have relied on qualitative analysis.

From the many studies of transnationalism that we analysed, promising strands of research have already emerged. These strands of research need to be based on clear, but necessarily transient, definitions and characteristics of transnationalism. This is crucial for the usability and applicability of transnationalism as a key concept for analysing and interpreting early twenty-first century societies; for instance, the close connection between transnationalism and telecommunications (defined as the use of the internet and social media in cross-border activities) highlights the porosity of spatio-temporal borders in the information era. In the contemporary world, consisting of hybrid augmented reality involving physical and digital spaces, transnationalism needs to be reconceptualised in terms of cognitive, imagined travel (Hillmann et al. 2018; Koikkalainen and Kyle 2016) and hybridised 
connected routes (Sánchez-Querubín and Rogers 2018). In the same vein, migrants' aspirations to return belong to the multiplicities of national and transnational identities that individuals build (or dismantle) while living in-between the hybrid, transnational spaces. Whether the return is then actualised or not does not make it a less real experience in terms of decisions, actions, and legal practices. In addition, definitions of transnationalism centring on bodily experiences, expressions, and performances, and how they are influenced by crossborder and national legal and normative requirements, remain to be explored.

Acknowledgements Open access funding provided by University of Turku (UTU) including Turku University Central Hospital.

Funding This study was partially funded by the Kone Foundation grant "Suomen Silta 3.0" (Grant Number 201608726).

Availability of data and material The data is not made available.

Code availability Not applicable.

\section{Compliance with ethical standards}

Conflicts of interest The authors declare that they have no conflict of interest.

Open Access This article is licensed under a Creative Commons Attribution 4.0 International License, which permits use, sharing, adaptation, distribution and reproduction in any medium or format, as long as you give appropriate credit to the original author(s) and the source, provide a link to the Creative Commons licence, and indicate if changes were made. The images or other third party material in this article are included in the article's Creative Commons licence, unless indicated otherwise in a credit line to the material. If material is not included in the article's Creative Commons licence and your intended use is not permitted by statutory regulation or exceeds the permitted use, you will need to obtain permission directly from the copyright holder. To view a copy of this licence, visit http://creativecommons.org/licenses/by/4.0/.

\section{References}

Aksoy, A., \& Robins, K. (2003). Banal transnationalism: The difference that television makes. In H. K. Karim (Ed.), The media of diaspora (pp. 102-117). London: Routledge.

Al-Ali, N., Black, R., \& Koser, K. (2001). The limits to transnationalism: Bosnian and Eritrean refugees in Europe as emerging transnational communities. Ethnic and Racial Studies, 24(4), 578-600.

Anderson, B. (1983). Imagined communities. London: Verso.

Baldassar, L., \& Merla, L. (2014). Locating transnational care circulation in migration and family studies. In L. Baldassar \& L. Merla (Eds.), Transnational families, migration and the circulation of care: Understanding mobility and absence in family life (pp. 25-58). Abingdon, New York: Routledge.

Bauböck, R. (2003). Towards a political theory of migrant transnationalism. International Migration Review, 37(3), 700-723.

Bauböck, R., \& Faist, T. (Eds.). (2010). Diaspora and transnationalism: Concepts, theories and methods. Amsterdam: Amsterdam University Press.

Beauchemin, C., \& Safi, M. (2020). 'Migrants' connections within and beyond borders: insights from the comparison of three categories of migrants in France. Ethnic and Racial Studies, 43(2), 255-274.

Bolognani, M. (2007). The myth of return: Dismissal, survival or revival? A Bradford example of transnationalism as a political instrument. Journal of Ethnic and Migration Studies, 33(1), 59-76.

Brown, H. E. (2016). Immigrant bodily incorporation: How the physical body structures identity, mobility, and transnationalism. Social Problems, 64(1), 14-29.

Carling, J. (2008). The human dynamics of migrant transnationalism. Ethnic and Racial Studies, 31(8), 1452-1477.

Carling, J., \& Erdal, M. B. (2014). Return migration and transnationalism: How are the two connected? International Migration, 52(6), 2-12.

Carling, J., \& Pettersen, S. V. (2014). Return migration intentions in the integration-transnationalism matrix. International Migration, 52(6), 13-30.

Chang, I. Y., Sam, M. P., \& Jackson, S. J. (2017). Transnationalism, return visits and identity negotiation: South Korean-New Zealanders and the Korean national sports festival. International Review for the Sociology of Sport, 52(3), 314-335.

Chen, W. (2013). The implications of social capital for the digital divides in America. The Information Society, 29(1), 13-25.

Choo, H. Y. (2006). Gendered modernity and ethnicized citizenship: North Korean settlers in contemporary South Korea. Gender \& Society, 20(5), 576-604.

Ciobanu, R. O., \& Ludwig-Dehm, S. M. (2020). Life in limbo: Old-age transnationalism. The Gerontologist, 60(2), 322-330.

Comola, M., \& Mendola, M. (2015). Formation of migrant networks. The Scandinavian Journal of Economics, 117(2), 592-618.

De Bree, J., Davids, T., \& De Haas, H. (2010). Post-return experiences and transnational belonging of return migrants: A Dutch-Moroccan case study. Global Networks, 10(4), 489-509.

De Haas, H., \& Fokkema, T. (2011). The effects of integration and transnational ties on international return migration intentions. Demographic Research, 25, 755-782.

Duval, D. T. (2004). Linking return visits and return migration among Commonwealth Eastern Caribbean migrants in Toronto. Global Networks, 4(1), 51-67. 
Ehrkamp, P. (2019). Geographies of migration III: Transit and transnationalism. Progress in Human Geography, 0309132519895317.

Erdal, M. B., \& Oeppen, C. (2013). Migrant balancing acts: Understanding the interactions between integration and transnationalism. Journal of Ethnic and Migration Studies, 39(6), 867-884.

Faist, T., \& Bilecen, B. (2017). Transnationalism-updated. COMCAD (Centre on Migration, Citizenship and Development) Working Papers 158. Available at: https://www. ssoar.info/ssoar/handle/document/55393. Accessed 17 July 2020.

Foner, N. (1997). What's new about transnationalism? New York immigrants today and at the turn of the century. $D i$ aspora: A Journal of Transnational Studies, 6(3), 355-375.

Gamburd, M. R. (2000). The Kitchen Spoon's Handle: Transnationalism and Sri Lanka's Migrant Housemaids. London: Cornell University Press.

Granovetter, M. S. (1973). The strength of weak ties. American Journal of Sociology, 78(6), 1360-1380.

Guarnizo, L. E. (1997). The emergence of a transnational social formation and the mirage of return migration among Dominican transmigrants. Identities Global Studies in Culture and Power, 4(2), 281-322.

Hillmann, F., Van Naerssen, T., \& Spaan, E. (Eds.). (2018). Trajectories and imaginaries in migration: The migrant actor in transnational space. London: Routledge.

Hirst, P. Q., \& Bader, V. (Eds.). (2001). Associative democracy: The real third way. Abingdon, New York: Frank Cass Publishers.

Hitchcock, P. (2003). Imaginary states: Studies in cultural transnationalism. Champaign: University of Illinois Press.

Horst, H. A. (2007). "You can't be two places at once": Rethinking transnationalism through Jamaican return migration. Identities: Global Studies in Culture and Power, 14(1-2), 63-83.

Hourani, G. (2012). Transnationalism from above: Homeland political parties of Lebanon and the Lebanese diaspora. SSRN 2211406

Iaria, V. (2014). Post-return transnationalism and the Iraqi displacement in Syria and Jordan. International Migration, 52(6), 43-56.

Innes, A. (2019). Colonial citizenship and everyday transnationalism: An immigrant's story. London: Routledge.

Itzigsohn, J., \& Saucedo, S. G. (2002). Immigrant incorporation and sociocultural transnationalism. International Migration Review, 36(3), 766-798.

Itzigsohn, J., et al. (1999). Mapping Dominican transnationalism: Narrow and broad transnational practices. Ethnic and Racial Studies, 22(2), 316-339.

Iwabuchi, K. (2019). Transnationalism, inter-nationalism and multicultural questions. In K. Smets, et al. (Eds.), The SAGE handbook of media and migration (pp. 34-39). London: SAGE.

Jones, R. C. (2019). The decline of migrant transnationalism with time abroad. Ethnic and Racial Studies, (on-line first).

Kaldor, M. (1999). Transnational civil society. In T. Dunne \& N. Wheeler (Eds.), Human rights in global politics (pp. 195-213). Cambridge: Cambridge University Press.

Kavoura, A., \& Tiago Borges, M. (2016). Understanding online communities on social networks via the notion of imagined communities: The case of TripAdvisor. International Journal of Web Based Communities, 12(3).

Kea, P. J. (2020). The transnational lives and third space subjectivities of British Nigerian girls. Global Networks, 20(1), 170-189.

Kearney, M. (1995). The local and the global: The anthropology of globalization and transnationalism. Annual Review of Anthropology, 24(1), 547-565.

Kelleher, D., et al. (2020). Examining the transnational health preferences of a group of Eastern European migrants relative to a European host population using the EQ-5D-5L. Social Science and Medicine, 246, 112801.

Kernalegenn, T., \& Van Haute, É. (2020). Political parties abroad: A new Arena for party politics. London: Routledge.

King, R., \& Christou, A. (2010). Diaspora, migration and transnationalism: Insights from the study of second-generation "returnees". In R. Bauböck \& T. Faist (Eds.), Diaspora and transnationalism: Concepts, theories and methods (pp. 167-183). Amsterdam: Amsterdam University Press.

King, R., \& Christou, A. (2014). Second-generation "return" to Greece: New dynamics of transnationalism and integration. International Migration, 52(6), 85-99.

Klingenberg, A., Luetz, J. M., Crawford, A. (2020). Transnationalism-recognizing the strengths of dual belonging for both migrant and society. Journal of International Migration and Integration, (on-line first).

Koikkalainen, S., \& Kyle, D. (2016). Imagining mobility: The prospective cognition question in migration research. Journal of Ethnic and Migration Studies, 42(5), 759-776.

Kunuroglu, F., Yagmur, K., Van De Vijver, F., \& Kroon, S. (2018). Motives for Turkish return migration from Western Europe: Home, sense of belonging, discrimination and transnationalism. Turkish Studies, 19(3), 422-450.

Levitt, P. (2001). The transnational villagers. Berkeley: University of California Press.

Li, W., \& Teixeira, C. (2007). Introduction: Immigrants and transnational experiences in world cities. GeoJournal, 68(2), 93-102.

Lietaert, I., Broekaert, E., \& Derluyn, I. (2017). The boundaries of transnationalism: The case of assisted voluntary return migrants. Global Networks, 17(3), 366-381.

Lionnet, F., \& Shi, S. (Eds.). (2005). Minor transnationalism. Durham: Duke University Press.

Lubbers, M. J. (2018). The missing link: Social network analysis in migration and transnationalism. Social Networks, 53, $1-3$.

Lucas, S., \& Purkayastha, B. (2007). "Where is home?" Here and there: Transnational experiences of home among Canadian migrants in the United States. GeoJournal, 68(2), 243-251.

Lutz, H. (2018). Care migration: The connectivity between care chains, care circulation and transnational social inequality. Current Sociology, 66(4), 577-589.

Lutz, H., \& Palenga-Möllenbeck, E. (2015). Global care chains. In A. Triandafyllidou (Ed.), Routledge handbook of immigration and refugee studies (pp. 139-144). Abingdon, New York: Routledge. 
Melly, C. (2010). Inside-out houses: Urban belonging and imagined futures in Dakar, Senegal. Comparative Studies in Society and History, 52(1), 37-65.

Merisalo, M., \& Jauhiainen, J. S. (2019). Digital divides among asylum-related migrants: Comparing Internet use and smartphone ownership. Tijdschrift voor Economische en Sociale Geografie, (on-line first).

Merisalo, M., \& Jauhiainen, J. S. (2020). Asylum-related migrants' social media use, mobility decisions and resilience. Journal of Immigrant \& Refugee Studies, (on-line first).

Mintz, S. W. (1998). The localization of anthropological practice: From area studies to transnationalism. Critique of Anthropology, 18(2), 117-133.

Molina, J. L., Petermann, S., \& Herz, A. (2014). Defining and measuring transnational social structures. Field Methods, 27(3), 223-243.

Moret, J. (2016). Cross-border mobility, transnationality and ethnicity as resources: European Somalis' post-migration mobility practices. Journal of Ethnic and Migration Studies, 42(9), 1455-1472.

Ong, A., \& Nonini, D. (Eds.). (2003). Ungrounded empires: The cultural politics of modern Chinese transnationalism. London: Routledge.

Østergaard-Nielsen, E. (2003). International migration and sending countries: Perceptions, policies and transnational relations. New York: Palgrave Macmillan.

Papadopoulos, D., \& Tsianos, V. (2008). The autonomy of migration: The animals of undocumented mobility. In A. Hickey-Moody \& P. Malins (Eds.), Deleuzian encounters. Studies in contemporary social issues (pp. 223-235). Basingstoke: Palgrave Macmillan.

Peck, S. (2020). Transnational social capital: The socio-spatialities of civil society. Global Networks, 20(1), 126-149.

Pelliccia, A. (2019). The Internet in a diasporic and transnational context: A case study of a Greek community in Italy. Journal of Greek Media \& Culture, 5(1), 21-44.

Pilati, K., \& Herman, B. (2020). Comparing engagement by migrants in domestic and in country-of-origin political activities across European cities. Acta Politica, 55(1), $103-129$.

Portes, A. (2001). Introduction: The debates and significance of immigrant transnationalism. Global Networks, 1(3), 181-194.

Portes, A. (2003). Conclusion: Theoretical convergencies and empirical evidence in the study of immigrant transnationalism. International Migration Review, 37(3), 874-892.

Portes, A., Guarnizo, L. E., \& Landolt, P. (1999). The study of transnationalism: Pitfalls and promise of an emergent research field. Ethnic and Racial Studies, 22(2), 217-237.

Pötzschke, S. (2012). The Europeanisation of everyday life: Cross-border practices and transnational identifications among EU and third-country citizens measuring transnational behaviours and identities. In EUCROSS working paper 4. Available at: https://www.ssoar.info/ssoar/handle/ document/39532. Accessed 17 July 2020.

Recchi, E., \& Favell, A. (Eds.). (2019). Everyday Europe: Social transnationalism in an unsettled continent. Bristol: Policy Press.
Reynolds, T. (2011). Caribbean second generation return migration: Identities, transnational family relationships and 'left behind' kin in Britain. Mobilities, 6(4), 535-552.

Rizvi, F. (2019). Global mobility, transnationalism and challenges for education. In M. Drinkwater, F. Rizvi, \& K. Edge (Eds.), Transnational perspectives on democracy, citizenship, human rights and peace education (pp. 27-50). New York: Bloomsbury Publishing.

Sahoo, A. K., \& Purkayastha, B. (Eds.). (2020). Routledge handbook of Indian transnationalism. London: Routledge.

Salih, R. (2003). Gender in transnationalism: Home, longing and belonging among Moroccan Migrant women. London: Routledge.

Sánchez-Querubín, N., \& Rogers, R. (2018). Connected routes: Migration studies with digital devices and platforms. Social Media + Society, 4(1), 2056305118764427.

Schiller, N. G., Basch, L., \& Blanc-Szanton, C. (1992a). Towards a definition of transnationalism. Annals of the New York Academy of Sciences, 645(1), 9-14.

Schiller, N. G., Basch, L., \& Blanc-Szanton, C. (1992b). Transnationalism: A new analytic framework for understanding migration. Annals of the New York Academy of Sciences, 645(1), 1-24.

Smith, M. P. (2003). Transnationalism, the state, and the extraterritorial citizen. Politics \& Society, 31(4), 467-502.

Smith, M. P., \& Guarnizo, L. E. (Eds.). (1998). Transnationalism from below. New Jersey: Transaction Publishers.

Sommer, E. (2020). Transnational entrepreneurial activities (TEA). In E. Sommer (Ed.), Social capital as a resource for migrant entrepreneurship (pp. 237-281). Wiesbaden: Springer.

Starikov, V. S., Ivanova, A. A., \& Nee, M. L. (2018). Transnationalism online: Exploring migration processes with large data sets. Monitoring of Public Opinion: Economic and Social Changes, 5, 213-232.

Sun, W., \& Sinclair, J. (2016). Media and communication in the Chinese Diaspora: Rethinking transnationalism. London: Routledge.

Tsuda, T. (2013). When the diaspora returns home: Ambivalent encounters with the ethnic homeland. In Q. Ato \& N. Hoboken (Eds.), A companion to diaspora and transnationalism (pp. 172-189). New York: Wiley-Blackwell.

Verdery, A. M., et al. (2018). Communication flows and the durability of a transnational social field. Social Networks, $53,57-71$.

Vertovec, S. (1999). Conceiving and researching transnationalism. Ethnic and Racial Studies, 22(2), 447-462.

Vertovec, S. (2003). Migration and other modes of transnationalism: Towards conceptual cross-fertilization. International Migration Review, 37(3), 641-665.

Vertovec, S. (2004). Migrant transnationalism and modes of transformation. International Migration Review, 38(3), 970-1001.

Vertovec, S. (2009). Transnationalism. London: Routledge.

Waldinger, R. (2013). Immigrant transnationalism. Current Sociology, 61(5-6), 756-777.

Wessendorf, S. (2007). "Roots migrants": Transnationalism and 'return' among second-generation Italians in Switzerland. Journal of Ethnic and Migration Studies, 33(7), 1083-1102. 
Westwood, S., \& Phizacklea, A. (2000). Trans-nationalism and the politics of belonging. New York: Psychology Press.

Wong, L. L. (2007). Transnationalism, active citizenship, and belonging in Canada. International Journal, 63(1), 79-99.

Wong, A. K. (2020). Queer vernacularism: Minor transnationalism across Hong Kong and Singapore. Cultural Dynamics, 0921374019900698.
Yoon, K. (2016). The migrant lives of the digital generation. Continuum, 30(4), 369-380.

Publisher's Note Springer Nature remains neutral with regard to jurisdictional claims in published maps and institutional affiliations. 